УДК 343.71

DOI https://doi.org/10.32837/pyuv.v0i4.630

\author{
С. М. Школа \\ orcid.org/0000-0003-0403-5916 \\ кандидат юридичних наук, доцент, \\ доцент кафедри крилінально-правових дисииплін \\ Дніпропетровського державного університету внутрішніх справ
}

\title{
СУБ'СКТ ПРИВЛАСНЕННЯ, РОЗТРАТИ АБО ЗАВОЛОДІННЯ ЧУЖИМ МАЙНОМ ШЛЯХОМ ЗЛОВЖИВАННЯ СЛУЖБОВОЮ ОСОБОЮ СВОЇМ СЛУЖБОВИМ СТАНОВИЩЕМ
}

Постановка проблеми. Враховуючи, що посягання на власність стали об'єктом кримінально-правової регламентації ще $з$ часів дії законів царя Хамурапі, цей інститут належить до найбільш досліджених у теорії кримінального права. Однак це не означає, що всі проблемні питання кримінально-правової охорони власності розв'язані одностайно й остаточно. Ч. 2 ст. 191 Кримінального кодексу (далі - КК) України передбачає відповідальність за привласнення, розтрату або заволодіння чужим майном шляхом зловживання службовою особою своїм службовим становищем. У теорії та практиці застосування цієї норми існують проблемні питання щодо визначення ознак суб'єкта вказаного діяння, співвідношення понять «службова» й «посадова» особа, обгрунтованості віднесення цього діяння до переліку корупційних кримінальних правопорушень, спірним є й віднесення до числа службових осіб тих або інших категорій службовців (лікарів, учителів, викладачів вищих навчальних закладів). Необхідність дослідження цих питань зумовлена тим, що за останні роки відбулися значні зміни в соціальному й економічному житті країни, які привели до зміни характеру кримінальних правопорушень, вчинюваних службовими особами, появі ряду проблем, що не знаходять цілком свого розв'язання в законодавстві й у науковій теоріі.

Питання кваліфікації кримінальних правопорушень проти власності корисливої спрямованості, в тому числі й привласнення, розтрати або заволодіння чужим майном шляхом зловживання службовою особою своїм службовим становищем, досліджувались, зокрема, В.О. Бажановим, Л.Д. Гаухманом, Г.А. Кригером, Г.Л. Кригер, Ю.І. Ляпуновим, П.С. Матишевським, А.О. Пінаєвим, А.А. Піонтковським та іншими вченими.

Метою дослідження $\epsilon$ визначення ознак суб'єкта привласнення, розтрати або заволодіння чужим майном шляхом зловживання службовою особою своїм службовим становищем 3 урахуванням сучасної теорії та практики застосування ч. 2 ст. 191 КК України.

Радянським кримінальним законодавством і КК України 1960 р. посадова особа визначалась як особа, яка здійснювала постійно чи тимчасово функції представника влади, а також обіймала постійно чи тимчасово в державних або громадських установах, організаціях чи на підприємствах посади, пов'язані з виконанням організаційно-розпорядчих або адміністративно-господарських обов'язків, чи виконувала такі обов'язки в зазначених установах, організаціях і на підприємствах за спеціальним повноваженням [1, с. 6-7]. Частково схоже визначення службової особи відбито й у чинному КК України. Службовими особами $\epsilon$ особи, які постійно, тимчасово чи за спеціальним повноваженням здійснюють функції представників влади чи місцевого самоврядування, а також постійно чи тимчасово обіймають в органах державної влади, органах місцевого самоврядування, на підприємствах, в установах чи організаціях посади, пов'язані з виконанням організаційно-розпорядчих чи адміністративно-господарських функцій, або виконують такі функції за спеціальним повноваженням, яким особа наділяється повноважним органом державної влади, органом місцевого самоврядування, центральним органом державного управління зі спеціальним статусом, повноважним органом чи повноважною службовою особою підприємства, установи, організації, судом або законом (ч. 3 ст. 18 КК) [2].

Водночас у ч. 4 ст. 18 КК України зазначено, що службовими особами також визнаються посадові особи іноземних держав (особи, які обіймають посади в законодавчому, виконавчому або судовому органі іноземної держави, в тому числі присяжні засідателі, інші особи, які здійснюють функції держави для іноземної держави, зокрема для державного органу або державного підприємства), іноземні третейські судді, особи, уповноважені розв'язувати цивільні, комерційні або трудові спори в іноземних державах у порядку, альтернативному судовому, посадові особи міжнародних організацій (працівники міжнародної організації чи будь-які інші особи, уповноважені такою організацією діяти від їі імені), а також члени міжнародних парламентських асамблей, учасником яких є Україна, й судді й посадові особи міжнародних судів [2].

Поняття службової особи, яке міститься в ч. 3 ст. 18 КК України, за своїми ознаками схоже 
3 поняттям посадової особи, яке містилось у КК України 1960 р. (ч. 1 ст. 164).

Паралельне закріплення в законодавстві двох понять без їхнього належного тлумачення та розмежування створювало труднощі в правозастосовній практиці. Визначення поняття «посадова особа», яке давалося Законом України «Про державну службу» від 16 грудня 1993 р., з кримінально-правовим тлумаченням цього терміну не збігалося, бо охоплювало тільки осіб органів державної влади й місцевого самоврядування, а КК України 1960 р. вів мову про посадових осіб усіх підприємств, установ та організацій [3].

Чинний Закон України «Про державну службу» від 10 грудня 2015 р. також не дає поняття «службова особа», а використовує «посадова особа». Разом із тим цей Закон у ч. 2 ст. 1 дає визначення іншого поняття - «державний службовець», яким є громадянин України, який обіймає посаду державної служби в органі державної влади, іншому державному органі, його апараті (секретаріаті) (далі - державний орган), одержує заробітну плату з коштів державного бюджету й здійснює встановлені для цієї посади повноваження, безпосередньо пов'язані з виконанням завдань і функцій такого державного органу, а також дотримується принципів державної служби [4].

Проблемне питання застосованої в законодавстві термінології та тлумачення юридичних визначень «посадова особа» й «службова особа» ускладнилося $з$ прийняттям Конституції України, яка визначила, що посадові й службові особи - це різні категорії суб'єктів, із різним правовим статусом і різною юридичною відповідальністю. Спеціалісти зазначали, що службовцями є всі працівники державних установ, але не всі вони - посадові особи. Тобто кримінально-правове поняття «службова особа» суперечить положенням Конституції України, адже в ст. 19 визначено, що органи державної влади й місцевого самоврядування, їх посадові особи повинні діяти лише на підставі, в межах повноважень та у спосіб, що передбачені Конституцією та законами України. Цим аргументується необхідність заміни в КК України терміну "службова особа» на «посадова особа». Наведена думка заслуговує на увагу, однак нею не охоплюються службові особи за межами сектора державного управління, місцевого самоврядування, адже й Конституція України, й чинний Закон України «Про державну службу» від 10 грудня 2015 р. не ведуть мови про службових осіб приватних підприємств, громадських організацій [3].

На наш погляд, розмежування понять службової та посадової осіб слід шукати в розрізі предмета регулювання (охорони) тієї чи іншої галузі права. Так, адміністративне право регулює суспільні відносини в діяльності органів державної влади. Тому для цілей такого регулювання законодав- цем використовуються поняття «посадова особа» й «державний службовець», передбачені Законом України «Про державну службу». Кримінальне ж право охороняє суспільні відносини, на які здатна вчинити посягання особа, ознаки якої законодавець визначив у понятті «службова особа», передбаченому КК України.

Саме тому це принципово різні поняття, оскільки їхнє призначення зумовлене предметом регулювання (охорони) тієї галузі права, до сфери якої вони належать.

У ч. 2 ст. $191 \mathrm{KК} \mathrm{України} \mathrm{така} \mathrm{додаткова} \mathrm{озна-}$ ка суб'єкта кримінального правопорушення, як «службова особа» пов'язана 3 можливістю такої особи використовувати службове становище під час вчинення привласнення, розтрати або заволодіння чужим майном. Водночас мається на увазі наявність у службової особи регламентованого законодавством переліку повноважень (прав та обов'язків), які надають можливості чинити вплив на прийняття тих чи інших рішень в тій юридичній особі, де вона працює.

Можливість службової особи чинити вказаний вплив не обмежується лише наявним у неї правовим статусом, зумовленим законодавством. Завдяки займаній посаді службова особа користується певним авторитетом серед підлеглих осіб та інших працівників, який надає можливості діяти не тільки в межах нормативно закріплених повноважень, а й виходити за них.

Так, наприклад, К., працюючи на посаді директора Бережницької середньої загальноосвітньої школи 1-3 ступенів Жидачівського району Львівської області, виконуючи відповідні адміністративно-господарські й організаційно-розпорядчі обов'язки, бувши службовою особою, умисно, шляхом зловживання своїм службовим становищем, вчинив розтрату бюджетних коштів, а саме складав табелі обліку робочого часу педагогічного персоналу Бережницької сільської ради в період часу з 09 вересня 2012 р. по 09 травня 2013 р., в яких вказав, що керівник гуртка В. проводила гурткову роботу по одній годині в тиждень, незважаючи на те, що фактично В. на роботу в ці місяці не приходила й занять 3 учнями в гуртку «Хореографічний» не проводила. Табель обліку робочого часу передавав бухгалтеру відділу освіти Жидачівської районної державної адміністрації Н. для нарахування зарплати В. Внаслідок вказаних дій К., зловживаючи своїм службовим становищем, вчинив розтрату бюджетних коштів на загальну суму 1312 грн 80 коп., з яких проведено нарахування на заробітну плату й перераховано внесків до державних цільових фондів на суму 349 грн 63 коп. [5].

Оскільки підприемства, установи й організації можуть бути різних форм власності, виникає питання щодо можливості визнання спеціальним суб'єктом (службовою особою) кримінального 
правопорушення, передбаченого ч. 2 ст. $191 \mathrm{KК}$ України, власника приватного підприємства.

Існує думка, що такого власника, який не має найманих працівників, не можна визнавати службовою особою, оскільки функціями службової особи не може охоплюватися керівництво самим собою чи своїм власним майном. Проте реєстрація в державних органах, обов'язкове ведення обліку й звітності господарської діяльності вказують на створення юридичної особи. Оскільки суб'єкт самостійно розпоряджається своїм майном, фінансами, укладає угоди, підписує звітні й фінансові документи, він виконуе адміністративно-господарські й організаційно-розпорядчі функції та $\epsilon$ службовою особою відповідно до іï кримінально-правового визначення. Адже для кваліфікації кримінального правопорушення визначальне значення мають не назва посади, не форма власності установи (організації, підприємства), а характер обов'язків, які виконує особа по службі. Власник юридичної особи керує не собою, а саме цією юридичною особою. Тобто визначальне тут те, що власник приватного підприємства може шляхом хай досить формального здійснення розпорядчих обов'язків породжувати за їхньою допомогою специфічні правові наслідки [3].

Ми погоджуємось із наведеною думкою, згідно 3 якою для визнання власника приватного підприємства службовою особою обов'язковою ознакою $є$ не наявність у нього підлеглих осіб і виконання організаційно-розпорядчих функцій щодо них, а можливість такого власника вчиняти дії, які визнаються юридичними фактами на підставі чинного законодавства та які за своєю компетенцією може вчинити лише службова особа.

Також хотілося б звернути увагу на неоднозначне вживання в різних складах кримінальних правопорушень поняття службової особи: «службова особа підприємства, установи, організації незалежно від форми власності», «службова особа підприемства, установи чи організації», «службова особа суб'єкта господарської діяльності» [6, с. 300-301]. На наш погляд, термінологія закону повинна бути уніфікованою, тому доцільно привести наведені поняття до єдиної форми.

Для вірного встановлення ознак службової особи, правильної кваліфікації кримінального правопорушення необхідно чітко визначити правовий статус особи, яка притягується до відповідальності, коло її повноважень і характер покладених на неї обов'язків. Дотримання цієї умови можливе лише в разі встановлення нормативного акту, який визначає зазначені повноваження та обов'язки. Невизначеність у вироках судів вказаних нормативних актів свідчить про недоведеність вини особи в привласненні, розтраті або заволодінні чужим майном шляхом зловживання службовою особою своїм службовим становищем.
Так, Тростянецьким районним судом Вінницької області притягнуто до кримінальної відповідальності Л., яка, працюючи на посаді головного бухгалтера Цибулівської сільської ради, бувши матеріально-відповідальною особою та особою, відповідальною за правильність ведення бухгалтерського обліку в сільській раді, у 2006 р., зловживаючи своїм службовим становищем, не маючи відповідного розпорядження голови Цибулівської сільської ради, провела зайве нарахування надбавки до заробітної плати працівників апарату сільської ради в сумі 3456 грн 75 коп., чим здійснила розтрату бюджетних коштів [7].

У такому випадку вироком суду не встановлені нормативні акти, які б визначали повноваження Л. щодо ведення бухгалтерського обліку в сільській раді, що надало їй можливості здійснити розтрату бюджетних коштів, а тому її вину у вчиненні кримінального правопорушення, передбаченого ч. 2 ст. 191 КК України, не можна назвати доведеною.

У слідчій і судовій практиці виникають питання щодо кваліфікації дій службових осіб, які в процесі заволодіння чужим майном не використовують своїх службових повноважень, проте чинять вплив на інших службових осіб і завдяки цьому заволодівають вказаним майном.

Так, наприклад, В., працюючи керівником Теплицького відділення кредитної спілки «Альянс Україна» й згідно 3 посадовою інструкцією бувши наділеною повноваженнями щодо укладання кредитних договорів, додаткових угод, договорів застави, договорів поруки, видачі кредитних коштів клієнтам та отримання від них плати за кредити й суми кредитів, тобто здійснюючи організаційно-розпорядчі повноваження, бувши службовою особою та, згідно з договором про повну матеріальну відповідальність від 10 грудня 2007 р., матеріально-відповідальною особою, протягом 2008 р. вчинила розтрату ввірених їй кредитною спілкою грошових коштів в інтересах третіх осіб.

Так, 21 січня 2008 р. В., зловживаючи своїм службовим становищем, умисно, на вмовляння та за сприяння заступника керівника Теплицького відділення кредитної спілки «Альянс Україна» К., із метою розтрати ввірених їй кредитною спілкою грошових коштів на користь К. здійснила оформлення договору кредиту за № 01108 Ктл від 21 січня 2008 р. на суму 4600 грн на ім'я 3., яка фактично не була позичальником за вказаним договором кредиту. У відповідних документах кредитної справи, імітуючи підпис 3., поставила підпис К., якій В. згідно з видатковим касовим ордером від 21 січня 2008 р. видала грошові кошти в сумі 4600 грн, чим було завдано матеріальної шкоди на вказану суму кредитній спілці «Альянс Україна». К. надалі використала кошти на свої потреби [8]. 
Дії заступника керівника Теплицького відділення кредитної спілки «Альянс Україна» К., яка є службовою особою, в наведеному прикладі слід кваліфікувати за ч. 5 ст. 27 і ч. 2 ст. 191 КК України як пособника в розтраті чужого майна шляхом зловживання службовою особою своїм службовим становищем.

Привласнення, розтрата або заволодіння чужим майном шляхом зловживання службовою особою своїм службовим становищем згідно з приміткою до ст. 45 КК України визнається корупційним кримінальним правопорушенням. Водночас суб'єктом цього правопорушення згідно зі ст. 18 КК України виступають як службові особи, визначення яких надається в ч. 3 цієї статті, так i посадові особи іноземних держав (особи, які обіймають посади в законодавчому, виконавчому або судовому органі іноземної держави, в тому числі присяжні засідателі, інші особи, які здійснюють функції держави для іноземної держави, зокрема для державного органу або державного підприємства), іноземні третейські судді, особи, уповноважені розв'язувати цивільні, комерційні або трудові спори в іноземних державах у порядку, альтернативному судовому, посадові особи міжнародних організацій (працівники міжнародної організації чи будь-які інші особи, уповноважені такою організацією діяти від її імені), а також члени міжнародних парламентських асамблей, учасником яких $є$ Україна, й судді й посадові особи міжнародних судів (ч. 4 ст. 18 КК України)).

Таке визначення суб'єкта кримінального правопорушення, передбаченого ч. 2 ст. 191 КК України, не відповідає визначенню суб'єктів, на яких поширюється дія Закону України «Про запобігання корупції від 14 жовтня 2014 р. (відповідно до ч. 3 цього Закону) [9].

Вважаємо, що для унеможливлення неоднозначного застосування кримінального й іншого законодавства України у сфері запобігання корупції доцільно узгодити термінологію, яка використовується в різних нормативно-правових актах, зокрема в частині визначення суб'єктів корупційних правопорушень.

Висновки. Таким чином, у ч. 2 ст. 191 КК України така додаткова ознака суб'єкта кримінального правопорушення, як «службова особа», пов'язана з можливістю такої особи використовувати службове становище під час вчинення привласнення, розтрати або заволодіння чужим майном. Водночас мається на увазі наявність у службової особи регламентованого законодавством переліку повноважень (прав та обов'язків), які надають можливості чинити вплив на прийняття тих чи інших рішень в тій юридичній особі, де вона працює.

Для визнання власника приватного підприємства службовою особою обов'язковою ознакою є не наявність у нього підлеглих осіб і виконання орга- нізаційно-розпорядчих функцій щодо них, а можливість такого власника вчиняти дії, які визнаються юридичними фактами на підставі чинного законодавства та які за своєю компетенцією може вчинити лише службова особа.

Також доцільним буде узгодження законодавчих визначень суб'єктів корупційних правопорушень, передбачених Законом України «Про запобігання корупції» від 14 жовтня 2014 р., із законодавчим визначенням суб'єкта корупційного кримінального правопорушення, передбаченого ч. 2 ст. 191 КК України.

\section{Jimepamypa}

1. Бантишев О.Ф. Злочини у сфері службової діяльності (питання кваліфікаціі) : навчальний посібник. Київ, 2002.127 с.

2. Кримінальний кодекс України : Закон України від 5 квітня 2001 р. № 2341-III / Верховна Рада України. URL: https://zakon.rada.gov.ua/laws/show/2341-14 (дата звернення: 15.10.2020).

3. Чернікова Р.О. Види та функції службових осіб за чинним кримінальним кодексом України. Allbest : електронна база знань. URL: https://knowledge.allbest. $\mathrm{ru} / \mathrm{law} / 2 \mathrm{c} 0 \mathrm{a} 65625 \mathrm{~b} 3 \mathrm{bd} 68 \mathrm{a} 4 \mathrm{c} 43 \mathrm{~b} 89521316 \mathrm{c} 26$ _0.html (дата звернення: 15.10.2020).

4. Про державну службу : Закон України від 10 грудня 2015 р. № 889-VIII / Верховна Рада України. URL: https://zakon.rada.gov.ua/laws/show/889-19 (дата звернення: 15.10.2020).

5. Кримінальна справа № 443/640/14-к. Архів Жидачівського районного суду Львівської області.

6. Гуторова Н.О. Кримінально-правова охорона державних фінансів України : монографія. Харків, 2001. $412 \mathrm{c}$.

7. Кримінальна справа № 1-192. Архів Тростянецького районного суду Вінницької області.

8. Кримінальна справа № 1-34/11. Архів Теплицького районного суду Вінницької області.

9. Про запобігання корупції : Закон України від 14 жовтня 2014 р. № 1700-VII / Верховна Рада України. URL: https://zakon.rada.gov.ua/laws/show/170018\#Text (дата звернення: 15.10 .2020 ).

\section{Анотація}

Школа С. М. Суб’єкт привласнення, розтрати або заволодіння чужим майном шляхом зловживання службовою особою своїм службовим становищем. Стаття.

У статті досліджуються ознаки суб'єкта привласнення, розтрати або заволодіння чужим майном шляхом зловживання службовою особою своїм службовим становищем. Поняття службової особи, яке міститься в ч. 3 ст. 18 Кримінального Кодексу України, за своїми ознаками схоже з поняттям посадової особи, яке містилось у Кримінальному Кодексі України 1960 р. Закон України «Про державну службу» від 10 грудня 2015 р. не дає поняття "службова особа», а використовує поняття «посадова особа». Паралельне закріплення в законодавстві двох понять без їхнього належного тлумачення та розмежування створює труднощі в правозастосовній практиці. Розмежування понять службової та посадової осіб слід шукати в розрізі предмета регулювання (охорони) тієї чи іншої галузі права. Це принципово різні поняття, оскільки їхнє призначення зумовлене предметом регулювання (охорони) тієї галузі права, 
до сфери якої вони належать. У ч. 2 ст. 191 Кримінального Кодексу України така додаткова ознака суб'єкта кримінального правопорушення, як «службова особа» пов'язана з можливістю такої особи використовувати службове становище в разі вчинення привласнення, розтрати або заволодіння чужим майном.

Для визнання власника приватного підприємства службовою особою обов' язковою ознакою є не наявність у нього підлеглих осіб і виконання організаційно-розпорядчих функцій щодо них, а можливість такого власника вчиняти дії, які визнаються юридичними фактами на підставі чинного законодавства та які за своєю компетенцією може вчинити лише службова особа.

Для вірного встановлення ознак службової особи необхідно чітко визначити правовий статус особи, яка притягується до відповідальності, коло її повноважень і характер покладених на неї обов'язків. Дотримання цієї умови можливе лише в разі встановлення нормативного акту, який визначає зазначені повноваження та обов'язки.

Визначення суб'єкта корупційного кримінального правопорушення, передбаченого ч. 2 ст. 191 Кримінального Кодексу України, не відповідає визначенню суб'єктів, на яких поширюється дія Закону України «Про запобігання корупції» від 14 жовтня 2014 р. № 1700-VII.

Ключові слова: суб'єкт кримінального правопорушення, привласнення, розтрата, заволодіння чужим майном, службова особа, зловживання службовим становищем.

\section{Summary}

Shkola S. M. Subject of appropriation, embezzlement or possession of other people's property by abuse of service person by his official position. - Article.

The article examines the signs of the subject of appropriation, embezzlement or possession of other people's property by abuse of service person by his official position. The concept of a service person contained in Part 3 of Art. 18 of the Criminal Code of Ukraine, on its own grounds, is similar to the concept of a post person contained in the Criminal Code of Ukraine in 1960. The Law of Ukraine "About Civil Service" of December 10, 2015 does not give the concept of "service person", but uses "post person". Parallel consolidation of two concepts in the legislation without their proper interpretation and distinction creates difficulties in law enforcement practice. The distinction between service person and post person should be sought in terms of the subject of regulation (protection) of a particular area of law. These are fundamentally different concepts, since their purpose is due to the subject of regulation (protection) of the field of law to which they relate. In Part 2 of Art. 191 of the Criminal Code of Ukraine such an additional feature of the subject of a criminal offence as a "service person" is connected with the possibility of such a person to use official position when committing appropriation, embezzlement or possession of other people's property.

To recognize the owner of a private enterprise as a service person, the obligatory feature is not the presence of subordinates and the performance of organizational and regulatory functions against them, but the ability of such owner to take actions that are recognized by legal facts on the basis of the current legislation and which only a service person can do by his competence.

For the correct establishment of signs of a service person, it is necessary to clearly define the legal status of the person who is brought to justice, the range of his powers and the nature of the duties assigned to him / her. Compliance with this condition is possible only if a normative act is established, which defines these powers and obligations.

Determination of the subject of corruption criminal offence stipulated by Part 2 of Art. 191 of the Criminal Code of Ukraine, does not meet the definition of subjects covered by the Law of Ukraine "About Prevention of Corruption" of October 14, 2014.

Key words: subject of criminal offense, appropriation, embezzlement, possession of other people's property, service person, abuse by official position. 